DEPARTMENT OF THE INTERIOR

UNI'TED STATES GEOLOGICAL SURVEY

GEORGE OTIS SMITH, DIRECTOR

Professional Paper 85-D

THE

JURASSIC FLORA OF CAPE IISBURNE

ALASKA

BY

F. H. KNOWLTON

Published January 28, 1914

PART D OF PROFESSIONAL PAPER 85, "CONTRIBUTIONS

TO GENERAL GEOLOGY 1913"

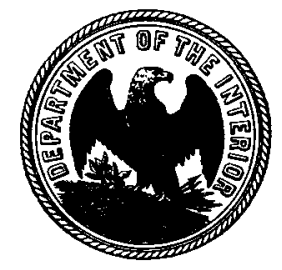

WASHINGTON

GOVERNMENT PRINTING OFFICE

1914 


\section{CONTENTS.}

Page.

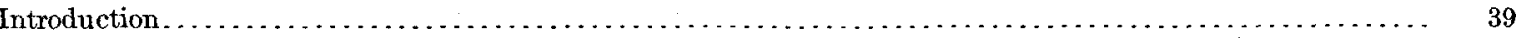

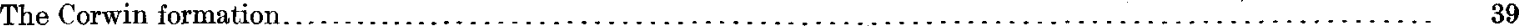

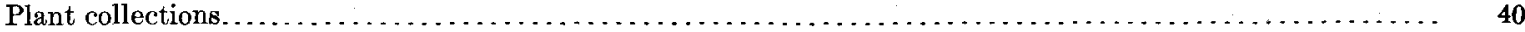

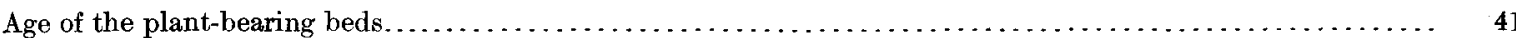

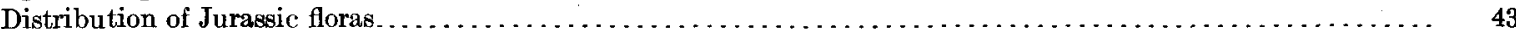

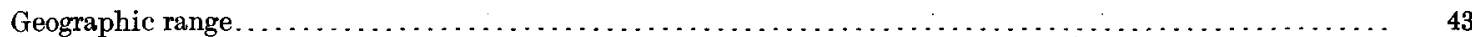

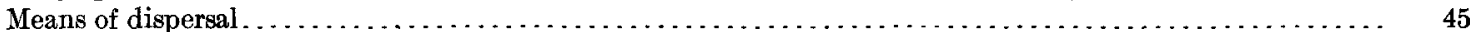

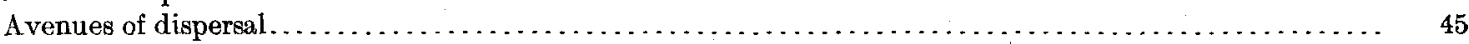

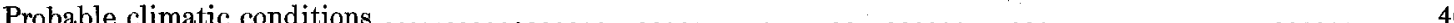

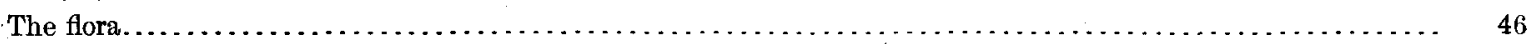

\section{ILLUSTRATIONS.}

Page.

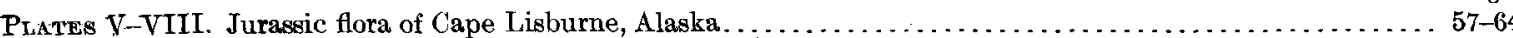




\title{
THE JURASSIC FLORA OF CAPE LISBURNE, AIAASKA.
}

\author{
By F. H. KNowlton.
}

\section{INTRODUCTION.}

A peculiar and absorbing interest attaches to the study of the fossil floras of the arctic regions, for they indicate climatic conditions very unlike those now existing in those regions. In place of the presents snow and ice and the scant, almost perpetually frozen soil which supports but a handful of depauperate plants, the conditions from at least late Paleozoic to middle Cenozoic time made an abundant and luxuriant vegetation possible, at least during certain periods. Although these lands are now so inhospitable, and hence but rarely visited, an astonishing amount of information concerning their fossil floras has been accumulated, and to this knowledge Alaska has contributed its full quota, though doubtless much more will ultimately be known.

The recent publication of a report by Prof. A. C. Seward on the Jurassic plants of Amurland, long known from the historic researches of Oswald Heer, has called to mind the existence of a considerable collection of similar plants from the vicinity of Cape Iisburne, Alaska, that has been in my possession for a number of years. As it is now possible, with Seward's paper in hand, to recognize still further the striking resemblances between the Jurassic floras of Alaska and Siberia, it seems an opportune time to present the results of this recent study. A preliminary examination of this material was made, and certain tentative identifications were adopted in a short report for the use of the geologists who collected it, but this is the first time it has been adequately described and figured.

The material considered in this paper was collected in 1904 by Arthur J. Collier, of the United States Geological Survey, while engaged in a study of the geology and coal resources of the Cape Lisburne region. ${ }^{1}$ The coal deposits are extensive and are the only mineral resources of the region known to be of commercial importance. Collier describes the locality as follows:

Cape Lisburne is the bold headland which marks the northwestern extremity of a land mass projecting into the Arctic Ocean from the western coast of Alaska between latitudes $68^{\circ}$ and $69^{\circ}$. It lies 160 miles north of the Arctic Circle, about 300 miles directly north of Nome, and is the only point in Alaska north of Bering Strait where hills above 1,000 feet in height approach the sea.

So far as known, the rocks of the Cape Lisburne region are all sedimentary. The age represented, with the approximate thickness of each, is given by Collier as follows: Devonian (?), 2,000 + feet; Lower Carboniferous [Mississippian], 4,500 + feet; Upper Jurassic, 15,000 + feet; Lower Cretaceous (?), 10,000 + feet; Pleistocene, 50 feet.

\section{THE CORWIN FORMATION.}

The Jurassic section to which the name Corwin formation has been given is described by Collier ${ }^{2}$ as follows:

The older of the Mesozoic formations, which takes its name from Corwin Bluff and the coal mines there located, is best exposed on the coast at a point 26 miles east of Cape Lisburne and thence extends northeastward to Cape Beaufort, a distance of 40 miles, which is the limit of this investigation. It is known to occur again near Wainwright Inlet 
100 miles beyond Cape Beaufort, and there is some reason for the belief that it is continuous to that point. The southern boundary of the formation extends in a southeasterly direction from the coast for about 12 miles, when it turns to the south. Beyond this the inland extension of the formation has not been determined. * * *

No contact between the Corwin formation and the Carboniferous [later determined to be in part Triassic] rocks described occurs within the limits of the area under investigation, though an unconformity is evident from certain beds of conglomerate containing pebbles derived from the Carboniferous. Lithologically the formation consists of rather thinly bedded shales, sandstones, conglomerates, and coal beds. Fossil plants occur in the shales wherever they have been closely examined. *** The formation throughout presents very little variation in lithologic character beyond the fact that in some portions of the section the shales are more carbonaceous, while in others they are more calcareous. Throughout the section there is nearly the same proportion of sandy beds.

As already indicated, the Corwin formation reaches the enormous thickness of over 15,000 feet and contains forty to fifty coal beds which range in thickness from 1 or 2 to over 30 feet, ten being over 4 feet thick and suitable for mining, the whole aggregating at least 150 feet.

\section{PLANT COLLECTIONS.}

The plant material obtained from the Corwin formation is comprised in nineteen collections, from as many localities, distributed along the coast from Corwin Bluff to Cape Beaufort, a distance of about 140 miles and apparently representing beds at different horizons throughout the formation. So far as the data at hand indicate, there is little or no variation in the flora through the whole thickness of the formation. When the preliminary examination of this material was made, and without knowing the relative stratigraphic position of any of the collections, a tentative attempt was made to fix the position in the section of a few of the lots. This attempt, however, was a failure, for certain collections which it seemed probable belonged near the base were in reality well distributed through the section and, for the present at least, the flora must be considered as a unit. As Collier has well said, "It is reasonable to expect some changes in the flora from the base to the top of a formation of such great thickness, but in this case the variation, if it exists, will probably be detected only by the paleobotanist after a critical personal examination of the section."

As Collier's collection was not the first to be made in the Cape Lisburne region, a brief review of previous collections and the age determinations given to them may be of interest.

Apparently the first to obtain material from the Corwin formation was A. Collie, who accompanied Capt. F. W. Beechey on his celebrated voyage to the Arctic. He first noted the presence of coal beds at Cape Beaufort and speaks of "carbonized impressions of reeds, both fluted and plain, generally flat," which were taken by William Buckland, ${ }^{1}$ who reported on the material, as indicating Carboniferous. As already noted, Collier found only Jurassic at Cape Beaufort.

Nearly 50 years passed before anything further was known from Cape Lisburne. From 1884 to about 1887 Henry D. Woolfe, while in the employ of the Pacific Steam Whaling Co., made annual visits to the region and sent to the United States National Museum a considerable collection of fossil plants. This material was studied by Lesquereux, ${ }^{2}$ who enumerated the following forms:

Aspidium oerstedi Heer.

Asplenium dicksonianum Heer.

Asplenium foersteri Deb. and Ett.

Baiera palmata Heer.

Chondrites filiciformis $\mathrm{n}$. $\mathrm{sp}$.

\author{
Irites alaskana $n . " s p$. \\ Pecopteris denticulata Heer. \\ Pinus? staratschini Heer. \\ Podozamites latipennis Heer. \\ Zamites alaskana n. sp.
}

Lesquereux concluded that the age of the beds was probably Neocomian.

In $1890 \mathrm{H}$. D. Dumars made a small collection of plants from the Corwin coal mine, which came ultimately to the United States National Museum. This collection, together with all of the Woolfe material, was elaborated by W. M. Fontaine for Lester F. Ward's monograph "Status of the Mesozoic floras of the United States." 3 Fontaine revised and changed many

1 Zoology of Captain Beechey's voyage, Geology, p. 173, London, 1839

2 U. S. Nat. Mus. Proc., vol. 10, p. 36, 1887; vol. 11, pp. 31-33, 1888.

3 U. S. Geol. Survey Mon. 48, pp. 153-175, Pls. XXXIX-XLY, 1905. 
of Lesquereux's determinations and as a final result of his studies gave the following list of species:

Chondrites filiciformis Lesq.

Dicksonia saportana Heer.

Onychiopsis psilotoides (Stokes and Webb) Ward.

Cladophlebis vaccensis Ward.

Cladophlebis alata Font.

Cladophlebis huttoni (Dunk.) Font.

Podozamites distantinervis Font.

Podozamites grandifolius? Font.

Baiera gracilis (Bean) Bunb.

Ginkgodium? alaskense Font.

Ginkgo digitata (Brongn.) Heer.

Ginkgo huttoni (Sternb.) Heer.

Ginkgo huttoni magnifolia Font.

Nageiopsis longifolia Font.

Fontaine discussed this flora at some length, his final conclusion being stated as follows: "The age of the formation yielding the Alaskan fossils, as indicated by them, is not older than the Lower Oolite and not younger than the Lower Cretaceous but is probably between them." On the basis of this statement Ward called the Cape Lisburne plants "Jurasso-Cretaceous."

In the preliminary study of Collier's material I took occasion to go over some of the identifications made by Fontaine and felt obliged to dissent from several of them. For example, the specimen which Fontaine determined as Podozamites distantinervis Font., a well-known Potomac species, I called $P$. lanceolatus latifolius, a Jurassic form. It appeared that Fontaine's great familiarity with the Potomac flora had led him to give undue weight to certain resemblances between them, and, as it then seemed to me, he made identifications which entirely vitiated the age determination. My conclusion was stated as follows: "I can see no valid reason for regarding this flora as other than Jurassic, or in any event as other than-identical with the flora from eastern Siberia, the Jurassic age of which is, so far as I know, universally accepted." I expressed a similar view in my paper "The Jurassic age of the "Jurassic flora of Oregon" $" 1$ and still entertain it.

The following is the complete list of species as given by me in the preliminary report made to Collier, ${ }^{2}$ with the corresponding identifications of the present paper in brackets:

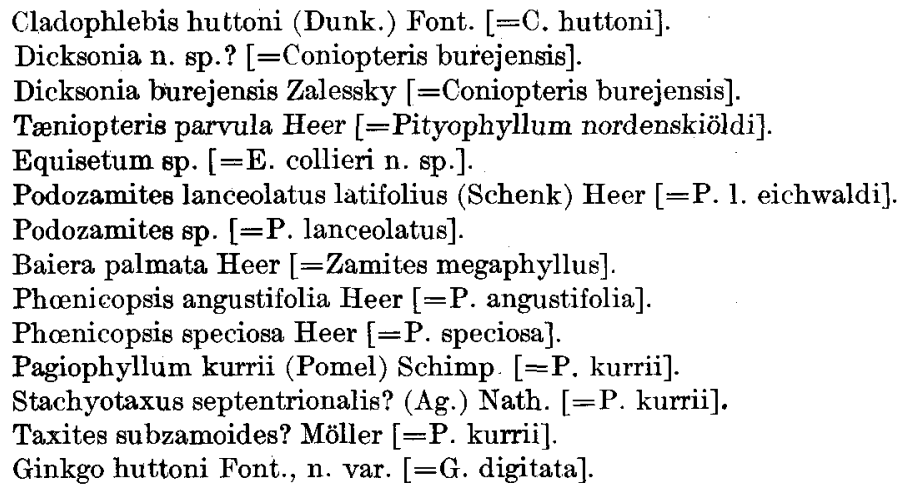

This revised list of species in the Collier collection is as follows:

Coniopteris hymenophylloides (Brongniart) Seward.

Coniopteris burejensis (Zalessky) Seward.

Cladophlebis huttoni (Dunker) Fontaine.

?Cladophlebis alata Fontaine.

Equisetum collieri n. sp.

Podozamites lanceolatus eichwaldi (Schimper) Heer. Podozamites lanceolatus (Lindley and Hutton) Braun.

Otozamites giganteus Thomas.

Zamites megaphyllus (Phillips) Seward.
Phœenicopsis speciosa Heer.

Phœnicopsis angustifolia Heer.

Elatides curvifolia (Dunker) Nathorst.

Pagiophyllum kurrii (Pomel) Schimper.

Pagiophyllum steenstrupi Bartholin?

Pityophyllum nordenskiöldi (Heer) Seward.

Fieldenia nordenskiöldi Nathorst.

Ginkgo digitata (Brongniart) Heer.

\section{AGE OF THE PLANT-BEARING BEDS.}

The bearing of these plants on the age of the beds in which they are found may now be considered. As already stated, the first material from the Cape Lisburne region was studied by Lesquereux, who regarded it as probably of Neocomian age. This material, together with 
a small later collection, was studied by Fontaine, who was somewhat in doubt as to whether it was Jurassic or lowest Cretaceous, the final compromise being to call the beds JurassoCretaceous. I have long regarded the material as of Jurassic age, and the critical study of the Collier collection appears to have proved this assignment beyond reasonable question.

Of the 17 species from the Cape Lisburne region noted in the present paper, the following also occur in Amurland, eastern Siberia: Coniopteris burejensis, C. hymenophylloides, Podozamites lanceolatus, P. l. eichwaldi, Phøicopsis speciosa, P. angustifolia, Ginkgo digitata, and Pityophyllum nordenskiöldi. These Amurland beds were regarded by Heer as belonging to that portion of the Middle Jurassic (Brown Jura) known as the Bathonian, and so far as known to me, this assignment has not been disputed. Seward in his late paper says: "The flora as a whole agrees closely with richer collections from Middle Jurassic strata."

In 1876 Heer ${ }^{1}$ described a large number of Jurassic plants from the Government of Irkutsk, eastern Siberia, and in 1911 Seward and Thomas ${ }^{2}$ reported on a small collection from the Balagansk district, in the same province. After making allowance for the changes in nomenclature there appear to be in these Irkutsk collections the following species in common with those from Cape Lisburne: Coniopteris burejensis?, Ginkgo digitata, Phonicopsis speciosa, $P$. angustifolia, Podozamites lanceolatus, $P$. l. eichwaldi, and Elatides cumifolia.

A large collection of plants, in the main very well preserved, from beds regarded as of Bathonian or lowest Callovian age, near Kamenka, district of Izium, Government of Kharkow, was described by Thomas ${ }^{3}$ in 1911. The following species from Cape Lisburne are represented in this flora: Coniopteris hymenophylloides, Cladophlebis huttoni, Ginkgo digitata, Elatides curvifolia, Otozamites giganteus, and Podozamites lanceolatus.

A small collection embracing 14 species from the western border of Mongolia, in Chinese Dzungaria, was described by Seward ${ }^{4}$ in 1911. The Mesozoic strata of this region, according to Obrutschew, who collected the plants, reach the enormous estimated thickness of 3,500 meters, thus approaching the thickness recorded by Collier for the Cape Lisburne region. The following species are common to the two localities: Coniopteris hymenophylloides, Ginkgo digitata, Phonicopsis angustifolia, and Podozamites lanceolatus. On the basis of the plants the beds are correlated by Seward with the Middle Jurassic rocks of England and other parts of the world. Seward calls attention to the "remarkable resemblance between Rhætic and Jurassic floras as regards general facies," and adds: "It appears to be certain that some types persisted from the Rhrtic period to the middle or even to the latest stage of the Jurassic era." This resemblance will be alluded to later.

Seward ${ }^{5}$ has described a small flora from Caucasia and Turkestan, from beds of Middle Jurassic age or older, which includes the following species found also at Cape Lisburne: Coniopteris hymenophylloides, Podozamites lanceolatus, Ginkgo digitata, and Phonicopsis angustifolia.

In 1876 Heer $^{6}$ described over 30 species of plants from the vicinity of Cape Boheman, Spitzbergen. The beds in which they were found were regarded by Heer as belonging to the Brown Jura (Bathonian), and Nathorst, ${ }^{7}$ who revised the flora in 1897, then confirmed this position, but later ${ }^{8}$ he procured evidence which induced him to regard the age as near or above the Oxfordian-that is, in the Upper or White Jura. The species from Cape Boheman represented in the rocks of Cape Lisburne are Podozamites lanceolatus, P. l. eichwaldi, Ginkgo digitata, Phonicopsis angustifolia, and Pityophyllum nordenskiöldi.

In the paper last cited. Nathorst also enumerates anew the Upper Jurassic plants from Advent Bay, Spitzbergen, Fieldenia nordenskiöldi and Elatides curvifolia being in common with Cape Lisburne. The flora of Franz Josef Land, regarded by Nathorst as younger than

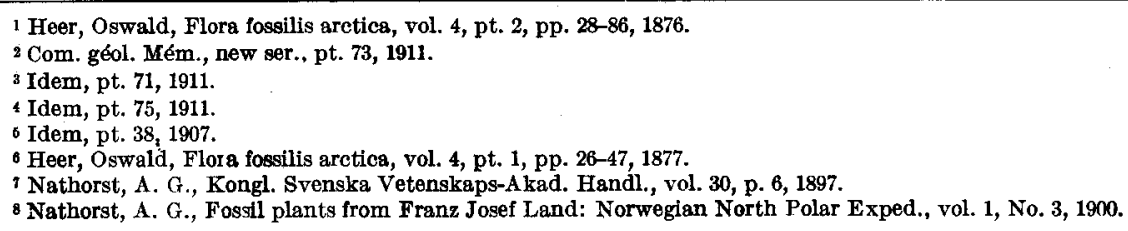


that of Cape Boheman and Siberia, appears to have nothing in common with that of the Alaskan locality.

The large and interesting flora of the island of Bornholm, which was first described by Bartholin and later and more fully by Möller, ${ }^{1}$ was regarded by the latter as of Rhætic or Liassic age. It is, as Seward has pointed out, "no doubt younger than the Rhætic floras of Scania, Tonkin, and Franconia, and the number of Lower Oolite species which it includes would seem to favor the view that its affinities are rather with Jurassic than with Rhætic floras of other regions." This statement is, at least to some extent, borne out by the following species from Cape Lisburne which are found also in Bornholm: Podozamites lanceolatus, Ginkga digitata, Phonicopsis angustifolia, and Pagiophyllum kurrii.

Turning now to the rich and well-exploited Jurassic floras of England, we find Coniopteris hymenophylloides, Ginkgo digitata, and Zamites megaphyllus, of the Great Oolite (Bathonian), in common with the Alaskan flora here discussed. Similar beds in Sutherland carry Coniopteris hymenophylloides, Ginkgo digitata, and Elatides curvifolia.

The rich Jurassic flora from Douglas County, Oreg., as worked up by Fontaine ${ }^{2}$ includes the following species which appear to be present also in the Cape Lisburne region, though not all are listed here under the same names: Coniopteris hymenophylloides, Thyrsopteris murrayana, Cladophlebis vaccensis, Podozamites lanceolatus, $P$. l. latifolius, $P$. pulchellus, Ginkgo digitata, and Phœnicopsis sp.

From the composition and wide distribution of this flora as outlined above, the final conclusion is reached that the Corwin formation of the Cape Lisburne region is undoubtedly Jurassic in age, belonging either in the upper part of the Middle Jurassic or Brown Jura, or the extreme lower portion of the Upper Jurassic or White Jura - that is to say, it is probably not older than the Bathonian and certainly not younger than the Oxfordian.

\section{DISTRIBUTION OF JURASSIC FLORAS.}

\section{GEOGRAPHIC RANGE.}

At this point it may be of general interest briefly to review the character and geographic range of Jurassic floras, especially as developed in Arctic and Antarctic regions. The wide areal distribution of Middle and Upper Jurassic floras has long been one of the marvels of plant distribution. The living flora, of course, affords many individual examples of wide distribution, such as those found throughout the Tropics of both hemispheres, and others, chiefly weeds, that have, largely through human agencies, spread widely over temperate lands, but altogether these plants form but an insignificant part of the whole flora, whereas in Jurassic time a large percentage of the whole flora was practically world-wide in its range.

In Alaska well north of the Arctic Circle is found the interesting flora described in this paper. Although only. a few fossil species are at present known to occur at Cape Lisburne, it is more than probable that the number would be greatly increased by careful examination, but the region is difficult of access and we must possibly await the exploitation of its coal resources before adequate investigation of the flora will be made.

'The Jurassic flora has been found at a number of other localities in Alaska, the farthest north being a point between Icy Cape and Wainwright Inlet, about 180 miles northeast of Cape Lisburne. Another locality is near Nikolai, in the Copper River region, which has afforded a single species of Sagenopteris that is closely related to a form from the Lower Oolite of Italy and has also been found in Oregon and California. This species came from a bed now known as the Kennicott formation, ${ }^{3}$ where it was found in association with marine invertebrates of Upper Jurassic age. The largest representation of Jurassic plants in Alaska, aside from that of Cape Lisburne, is found on the north shore of Cook Inlet, where seven or eight species were obtained. These occur in the "Enochkin formation" of Stanton and Martin, ${ }^{4}$ in

1 Möller, Hjalmar, Kongl. Svenska Vetenskaps-A kad. Handl., vol. 36, No. 6, 1903.

2 U. S. Geol. Survey Mon. 48, pp. 47-145, Pls. VI-XXXVIII, 1905.

${ }^{3}$ U. S. Geol. Survey Bull. 448, pp. 31-43, 1911.

4 Geol. Soc. America Bull., vol. 16, pp. 397 et seq., 1905.

$19205^{\circ}-14-2$ 
intimate association with marine shells regarded by these authors as the equivalent of the Callovian of European standards, or the upper part of the Lower Oolite of English geologists. The last Alaskan locality to be mentioned is Herendeen Bay, which has yielded a single species of Pterophyllum.

The only other important North American localities are those in Oregon and California, which together have afforded 101 forms. The collections from these localities are especially rich in forms of Cladophlebis, Tæniopteris, Sagenopteris, Nilsonia, Pterophyllum, Ctenis, Ctenophyllum, Podozamites, and Ginkgo. No less than 47 per cent of these species are found also in Jurassic beds in other parts of the world, notably in Alaska, eastern Siberia, and Yorkshire, England.

The areas geographically nearest to the Alaskan localities are those of eastern Siberia. In 1876 Heer published his first paper on the flora of these areas, which included material from Kajamundung, Ust-Bali, the upper Amur River, and Bureja. This was supplemented in later years by the study of further material from the original localities as well as from Lena Delta, etc. The total number of species finally aggregated about 100, and many of them have since been identified in widely scattered parts of the world, the greatest number being common to the beds in Oregon and California and in Yorkshire, England.

As a complete enumeration of the Jurassic floras of the world is impossible for lack of space in the present connection, the following list of localities may be given as a partial indication of their wide range:

United States:

South Dakota.

Wyoming.

California.

Alaska: Oregon.

Cape Lisburne.

Near Wainwright Inlet.

Nikolai.

Cook Inlet.

Herendeen Bay.

England: Yorkshire.

Scotland: Sutherland.

France: Mammers.

Germany:

Franco-Swabian area.

Northeastern area.

Austria-Hungary:

Steierdorf, Banat.

Crojic, Galicia.

- Krakau.

Italy.

Switzerland.

Portugal.

Sweden.

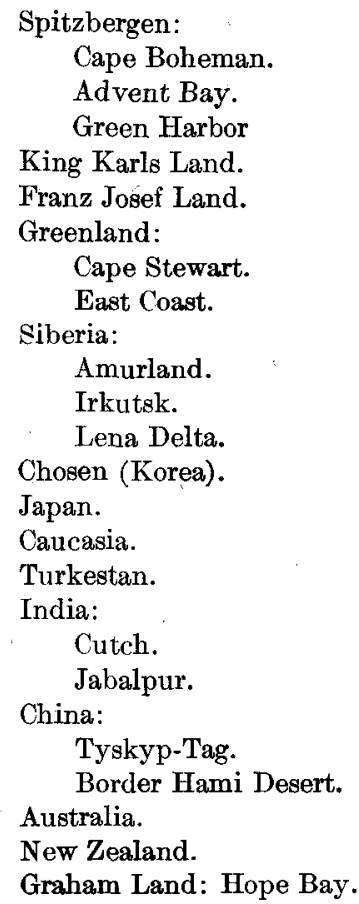

The flora of Graham Land, which has recently been carefully elaborated by Halle, ${ }^{1}$ is worthy of more than passing notice. This flora comprises 61 forms dispersed among the larger groups as follows: Filicales 25, Cycadales 17, Coniferales 16, unknown 3 . It is of interest to note that the Ginkgoales, which form an important and varied element in the northern hemisphere, are entirely absent from the Antarctic locality, as indeed they are from the Gondwanas of India, and that Podozamites, which is abundant and variable in the north, is absent from the Hope Bay collection and is represented only by doubtful fragments in the Indian localities. Of the 22 species from Graham Land that were previously known, 9 are common to the Lower

1 Halle, T. G., Mesozoic flora of Graham Land: Wissensch. Ergebnisse der schwedischen Südpolar-Expedition, 1901-1903, vol. 3, pt. 14, pp. 1-123, PIs. I-IX, 1913. 
Oolite of Yorkshire, England, 8 to the Upper Gondwanas of India, and 5 to the Jurassic of California and Oregon. In the nearest continent, South America, there are no floras of any importance that can be considered contemporaneous with this Antarctic flora.

With the foregoing outline of the distribution of Jurassic floras in mind, we are perhaps in a position to draw certain tentative conclusions as to their probable avenues and means of dispersal and elimatic requirements. The systematic groups with which we mainly have to deal are the Filicales, Equisetales, Cycadales, Ginkgoales, and Coniferales.

\section{MEANS OF DISPERSAL.}

The chief factors which are adduced to explain the distribution of living plants are animals, especially birds and mammals; water, especially streams and ocean currents; air currents; and, of course, human agencies.

In considering the distribution of Jurassic plants we may at once eliminate mammals, which were in Jurassic time on the threshold of their development, and birds, which were represented by a single known type (Archæopteryx) that at best must have enjoyed but limited powers of flight. There remain, therefore, only air and water transportation to account for the distribution of Jurassic plants. None of the plants is believed to have possessed any marked mechanism for wide and systematic dispersal.

The ferns of the Jurassic period are believed to have been homosporous, which implies the production of vast numbers of spores of relatively short-lived vitality. A considerable number of living ferns having spores of this character are widely distributed on both hemispheres. The male fern is an example; a single plant, according to Bower, may produce in one season 5,000,000 spores, which are particularly well adapted to wind dispersal. That ferns may pass over at least 25 miles of open water is shown by Treub, who found that on the island of Karakatau, which had been completely wrecked and sterilized by a volcanic outburst, within three years 12 species had already become reestablished. While the air currents may have been competent to accomplish this, the possibility of other agencies, such as transportation by birds, ocean currents, or man, should not be ignored.

The Equisetales were not an important element in the Jurassic flora, being mostly represented by fragmentary material referred to Equisetum or Equisetites. Although many of the living species enjoy a wide distribution, little evidence is available as to their means of dispersal.

The Cycadales are seed-bearing plants, the seeds being of small or medium size. In the living species the seeds sink in fresh water and presumably would do the same in salt water. The length of time they would retain their vitality in salt water is problematical, though probably it would be very short. Their transportation for any great distance by water is open to question.

The Ginkgoales are very distinctly a waning type; in fact, they have come almost to the vanishing point, for the single living species is not believed to exist in a purely wild state. The identification of the early forms now commonly referred to the Ginkgoales is founded mainly on the foliage organs, and their seeds are not certainly known, but since the discovery of true Ginkgo in late Triassic or early Jurassic beds, and in practically its present form, the seeds have not infrequently been found. These seeds, like those of the living species, are of large size. They have no special means for extended dispersal.

In the living Coniferales there are certain minor devices for limited seed dispersal, such as variously winged seeds, but nothing that is especially remarkable. The seeds of Jurassic Coniferales, so far as known, possessed no special devices for wider dissemination than that usually taking place on a land surface.

\section{AVENUES OF DISPERSAL.}

The data presented in the foregoing paragraphs regarding the means for dispersal would seem to indicate a practically continuous land connection between the several localities during Jurassic time. With the possible exception of the ferns, whose spores might have been trans- 
ported by air currents over very considerable distances of open water, none of the types appear to have possessed any mechanism or device by which they could have spread so widely without a practically continuous land route. It is of course possible that masses of earth covered with living vegetation-floating islands, so called-may have been torn from the land by streams and carried intact for considerable distances into the sea, as similar "islands" are now transported by the Amazon and other rivers, but the distance over which such masses would be effective in colonization is relatively short.

The striking similarity between the Jurassic floras of northwestern North America and eastern Siberia shows that the land connection between these localities during Jurassic time must have been practically continuous. The known presence of Jurassic beds at Herendeen Bay on the Aleutian Islands is at least a partial confirmation of the presence of this land bridge. If we may assume that the land adjacent to what is now Bering Sea was the centeror at least an important center-of distribution for the Jurassic floras, then, with communication established between the two continents, the way was open for a wide range over the northern hemisphere.

The presence of a well-marked Jurassic flora in the Antarctic ragion goes far toward justifying the presumption of a former land connection to that region, fer the present distance is so great as to preclude the reasonable probability that the flora could have reached there otherwise.

\section{PROBABIE CIIMATIC CONDITIONS.}

With the abundant data now available certain tentative conclusions may perhaps be drawn as to the climatic conditions which existed during the life of the Jurassic flora. There is no evidence that this flora was depauperate or pinched as the result of adverse climate. On the contrary, the presence of large and luxuriant ferns, many of them tree ferns, and cycads, and of very abundant and large-sized leaves of Ginkgo, etc., especially in localities far north of the Arctic Circle, affords every evidence that the conditions of growth were favorable From the wide distribution of genera and species it appears that the conditions were also relatively uniform. In other words, there must have been abundant or sufficient moisture and a temperature that would permit the growth of such plants. Knowledge of the probable moisture and temperature requirements of a flora now represented only by fossil remains must be gained by a study of the nearest related living flora. On this basis it seems safe to assume that the Jurassic flora indicates a moist, warm, possibly subtropical climate.

\section{THE FLORA.}

\section{Coniopteris BUReJensis (Zalessky) Seward.}

Plate V, figure 1.

Coniopteris burejensis (Zalessky) Seward, Jurassic plants from Amurland: Com. géol. Mém., new ser., pt. 81, p. 22, P1. I, figs. 1-5; P1. III, figs. 18-21, 1912.

, Dicksonia burejensis Zalessky, Notes paleophytologiques: Com. géol. Bull., vol. 22, p. 192, Pl. III, figs. 1-4; Pl. IV, figs. 1-5, 1904; Knowlton, in Collier, U. S. Geol. Survey Bull. 278, p. 29, 1906.

Dicksonia n. sp., Knowlton, in Collier, loc. cit.

Cladophlebis vaccensis Ward, Fontaine, in Ward, U. S. Geol. Survey Mon. 48, p. 157, Pl. XXXIX, figs. 7, 8, 1905.

In 1904 Zalessky described a fruiting fern from Amurland under the name Dicksonia burejensis, at the same time calling attention to its resemblance to Dicksonia coriacea Schenk, ${ }^{1}$ from the Jurassic of China, D. concinna Heer, from Amurland, etc. In his recent work, cited above, Seward redescribed and refigured the Zalessky specimens, together with additional material recently procured, under tae name Coniopteris burejensis, largely on the ground that the fossil is undoubtedly coseneric with Coniopteris hymenophylloides. If it is to be held that Coniopteris is $\mathbf{c o}^{-}$-ger aric with Dicksonia, then the former is untenable, for it dates from 1849, while Dicksonia was founded in 1788. However, as there is some doubt as to their

1 Schenk, A., Jurassische Pflanzen, in Richthofen's China, vol. 4, p. 254, Pl. LI, fig. 2; Pl. LII, figs. 5, 6, 1883. 
generic identity it may be well enough to retain the form under Coniopteris. It has usually been assumed that these plants belong to the family Cyatheacex, but of this more will be said later.

The salient features of Coniopteris burejensis are described by Seward as follows:

Frond bipinnate or probably tripinnate; pinnæ linear-lanceolate, attached to a comparatively slender rachis along the margins of which the pinnæ axes and the lamina of the basal pinnule on the lower side of the pinna are decurrent. The pinnules may be oval and serrate, like those of $C$. hymenophylloides, or longer and narrower, the linear lamina being serrate, or more deeply dissected into small oval segments; the latter form appears to be identical with that of some of the specimens described by Heer as Dicksonia gracilis and D. glehniana. In the larger examples the rackis is broader; the more widely separated pinnæ give a more open habit to the leaf, in marked contrast to the more compact form. The venation is of the Sphenopteris type.

In spite of Seward's elaborate explanation of the diversity in form and appearance of the sterile fronds referred to $C$. burejensis, it is difficult to believe that all are correctly referable to a single species. The long, narrow pinnæ with linear serrate laminæ (cf. figs. 18 and 20 of Seward's Pl. III) may very well be the sterile portions of the form that bore the fruiting specimen, but it would seem that the longer, oval, slightly serrate pinnules such as are shown in his Plate III, figure 19, are too different to have come from the same species. However, the collection may have contained many specimens that were not figured and some of these may bridge the apparent differences.

The fine fruiting specimen from Cape Lisburne shown in Plate $\mathrm{V}$ of the present paper is referred with much certainty to $C$. burejensis. It is a frond of large size, being probably between 30 and 40 centimeters in length and at least 20 centimeters broad. It is tripinnatified, or quadripinnate. The main rachis, which is over 3 millimeters in diameter and slightly zigzag, was evidently very stiff and rigid. The primary pinnæ are remote, alternate, at irregular distances, and spreading at the tips, giving the frond a very open, spreading effect. The rachis is relatively strong and somewhat angled. The secondary pinnæ are also alternate, sessile, lanceolate in general outline, and cut into numerous linear, deeply cut pinnules. The sori are terminal on slightly reduced laminæ.

The single specimen referred by Fontaine $^{1}$ to Cladophlebis vaccensis Ward, a species first described from the Jurassic of Oregon, is at best very obscure. It does not have the nervation ascribed to $C$. vaccensis, though in the shape of the pinnules there is not much difference. It is undoubtedly the same as the form shown in Zalessky's Plate III, figures 1, 1a, and refigured by Seward in his Plate III, figure 19, and is to be referred to Coniopteris burejensis.

\section{Coniopteris hymenophylloides (Brongniart) Seward.}

Plate $V$, figure 2 .

Coniopteris hymenophylloides (Brongniart) Seward, Jurussic flora of the Yorkshire coasi, p. 98, rl. XVI, figs. 4-6; P1. XVII, figs. 3, 6-8; Pl. XX, figs. 1, 2; Pl. XXI, figs. 1-3, 3a, 4, 4a, 1900; Fontaine, in Ward, U. S. Geol. Survey Mon. 48, p. 59, P1. VIII, figs. $1-3,1905$.

Sphenopteris hymenophylloides Brongniart, Prodrome. pp. 51. 198 [nomen], 1828; Histoire des végétaux fossiles, p. 189, Pl. LVI, figs. 4, 4b, 1829.

Adiantites amurensis Heer, Flora fossilis arctica, vol. 4. pt. 2, p. 94. Pl. XXI, figs. 6a, b; enlarged, figs. 6, c, d, 1876.

This is one of the most abundant and widely distributed of Jurassic plants, having been reported from the Antarctic, many localities throughout the Arctic, Siberia, China, Japan, Germany, France, England, and Oregon, and now from Alaska. As might be expected from the number of students who have handled it, it has been reported under several generic names (Sphenopteris, Thyrsopteris, Dicksonia, Adiantites, etc.), but it all seems conspecific and is best included under the somewhat noncommittal name Coniopteris.

This species is represented in the Cape Lisburne material by the single pinna figured, but fortunately this fragment is excellently preserved and there can be no doubt as to the correctness of its identification. It is, for instance, not to be distinguished from a specimen from the Jurassic of Yorkshire, England, figured by Seward. ${ }^{2}$

1 Fontaine, W. M., U. S. Geol. Survey Mon. 48, p. 157, Pl. XXXIX, figs. 7, 8, 1905

2 Seward, A. C., Jurassic flora of the Yorkshire coast, Pl. XVI, fig. 6, 1900. 
The specimen from Douglas County, Oreg., figured by Fontaine, ${ }^{1}$ has probably been correctly determined but is an indistinctly preserved fragment. The enlargements (figs. 2, 3) which purport to show the sori are, however, entirely incorrect, there being really no trace of the fruiting condition. The slightly involute margins of the tips of the pinnules were evidently mistaken by the artist for immature sori.

A comparison of the specimen from Cape Lisburne with Adiantites amurensis from Amurland as figured by Heer ${ }^{2}$ shows them to be undoubtedly identical, and, as suggested by Seward, ${ }^{3}$ there is no doubt about referring the Amurland specimen to Coniopteris hymenophylloides.

Cladophlebis huttoni (Dunker) Fontaine.

Plate VI, figure 3.

Cladophlebis huttoni. (Dunker) Fontaine, in Ward, U. S. Geol. Survey Mon. 48, p. 161, Pls. XLI-XLIII, 1905; Knowlton, in Collier, U. S. Geol. Survey Bull. 278, p. 29, 1906.

This species - one of the most abundant ferns in the Cape Lisburne region-has been so fully described and illustrated by Fontaine in the publication above cited that it is unnecessary again to go over the ground. The one or two examples from the Collier collection are here figured simply for the purpose of. showing that they are undoubtedly the same as the specimens identified by Fontaine as Cladophlebis. huttoni (Dunker). From the general shape and disposition of the pinnæ and pinnules, as well as the character of the nervation, there can be no doubt, it would seem, as to the correctness of referring these fronds to the genus Cladophlebis, but whether they are to be positively identified with Dunker's Neuropteris huttoni, ${ }^{4}$ from the Wealden of Hanover, is or may be quite a different thing. Fontaine is very positive on this point, saying: "This fern [Neuropteris huttoni] has an uncommon aspect, and it resembles so closely the ferns from. Alaska that there can be no doubt that they belong to the same species," but of this I am not so sure. It appears that only one fragment of the Hanoverian plant was found, this being a portion of a very strong rachis about 5.5 centimeters long and two more or less perfect pinnæ. Dunker's figure was copied by Schimper, ${ }^{5}$ who changed the name to Alethopteris huttoni, and the original specimen was later studied and again figured by Schenk. ${ }^{6}$. Schenk's figure differs somewhat from the original one, showing apparently that the specimen is really somewhat less perfect than would appear from Dunker's figure. It seems not unlikely that this Hanoverian plant should be referred to Cladophlebis denticulata (Brongniart); at least it seems strikingly similar to some that have been so referred-such, for instance, as one figured by Seward ${ }^{7}$ from the Jurassic of Yorkshire.

The figure of the type specimen of Dunker's plant shows the pinnæ to be, as in Cladophlebis denticulata, sessile but not decurrent on the main rachis, whereas in the Alaskan fronds the pinnæ are distinctly decurrent and, as Fontaine pointed out, there is an occasional pinnule on the main rachis between the insertions of the pinnæ. It was undoubtedly a very large fern. One specimen in the Dumars collection-shown in Plate XLI of Fontaine's report-is 32 centimeters in length, and as it lacks both base and apex was probably twice as long when perfect. The main rachis in this example was more than 5 millimeters thick. The secondary pinnæ have a tendency to be opposite on the rachis, though in the upper portion they may become somewhat alternate. They arise at an angle of about $45^{\circ}$ and curve outward slightly so as to become approximately at right angles to the rachis. In the lower and middle portions of the frond the pinnæ are cut deeply into ovate-lanceolate, slightly falcate divisions or pinnules, these being mainly entire, though some of them are provided with a few low teeth; the pinnules are for the most part rather acute. The lower pinnules of the lower ultimate pinnæ

1 Fontaine, W. M., U. S. Geol. Survey Mon. 48, Pl. VIII, fig. 1, 1905.

2 Heer, Oswald, Flora fossilis arctica, vol, 4, pt. 2, Pl. XXI, figs. 6a-d, 1876.

3 Seward, A. C., Com. géol. Mém., new ser., pt. 81, p. 19, 1912.

4 Dunker, W. B. R. H., Monographie der norddeutschen Wealdenbildung, p. 9, Pl. VIII, fig. 1, 1846.

5 Schimper, W. P., Traité de paléontologie végétale, vol, 1, p. 570, Atlas, PI. XXXI, fig. 10, 1869.

6 Schenk, A., Palæontographica, vol. 19, p. 217, Pl. XXIX [VIII], figs. 1, 1a, 1871.

7 Seward, A. C., Jurassic flora of the Yorkshire coast, Pl. XIV, fig. 1, 1900. 
are least united. Toward the ends of the ultimate pinnæ and in the terminal portions of the compound ends they are more and more united and pass into lobes and teeth, the size being at the same time diminished.

The nervation is described by Fontaine as follows:

The midnerve goes off very obliquely and at about two-thirds the distance to the end of the pinnule splits up into branches, after the fashion of Cladophlebis, so that the plant is a well-marked type of that genus and in the absence of fructification must be placed in it. The lateral nerves, in proportion to the size of the pinnules, are quite slender. They are immersed in the leaf substance and are not conspicuous. They go off very obliquely and are forked one or more times. The lowest are the most copiously branched. The forking is notably low down on the nerve, so that the branches are unusually long. On the lower side of the base of the pinnules one or more lateral nerves go off from the main rachis. In the more separated pinnules the lower lateral nerves curve away from the midnerve, but in the lobed and dentate forms the interior basal ones often curve inward toward it.

On taking everything into account it seems probable that this fern should receive a new name, but it is so robust and abundant a form that it probably had a wide distribution in Arctic lands, not being confined to the vicinity of Cape Lisburne, and rather than give it a name which might possibly prove to be a synonym of some form known from less complete material, I am permitting it to remain under the name given by Fontaine. It is very much to be doubted, however, that this fern is identical with the Neuropteris huttoni of Dunker.

\section{?Cladophlebis alata Fontaine.}

Plate V, figures 3, 4; Plate VI, figure 4.

?Cladophlebis alata Fontaine, in Ward, U. S. Geol. Survey Mon. 48, p. 158, PI. XXXIX, figs. 9-1I; PI. XL, 1905. Onychiopsis psilotoides (Stokes and Webb) Ward, idem, p. 155, Pl. XXXIX, figs. 3-6.

Pecopteris denticulata Heer, Lesquereux, U. S. Nat. Mus. Proc., vol. 11, p. 32, 1888.

It is with much hesitation that this species is permitted to remain under the designation given it by Fontaine in his review of the flora of Cape Lisburne, especially in view of the fact that Berry ${ }^{1}$ has merged the original $C$. alata with $C$. browniana (Dunker) Seward, a common form in the Patuxent and Arundel formations of Maryland and Virginia. That it is identical with the Potomac forms is extremely doubtful, but that it is the same as the numerous specimens from Cape Lisburne that were so designated by Fontaine there can of course be no question. At first it was thought that this form represented the sterile foliage of Coniopteris burejensis, and this supposition may ultimately be verified. For instance, the portion of the sterile pinna shown in Plate $\mathrm{V}$, figure 4, is certainly strikingly similar to the upper pinna on the righthand side of the figure of $C$. burejensis shown in Plate V. They are of about the same size, have the linear pinnules set at the same strict angle, and are cut nearly to the same degree.

It is not to be denied that the sterile portions of the specimens here called Cladophlebis alata have a rather striking resemblance to Onychiopsis psilotoides (or mantelli, as it is more frequently called). Thus, the very large lower pinna shown in Plate V, figure 3, is similar in general appearance to the figure given by Seward ${ }^{2}$ of a specimen. of $O$. mantelli from the English Wealden. Both these specimens show well the strict habit of the plants, and both lack the finer details of the outlines of the ultimate divisions. In the Alaskan specimen the pinnules are somewhat larger, but otherwise the difference is apparently not great. It was, of course, this general resemblance which induced Fontaine ${ }^{3}$ to identify certain specimens in the earlier collections as Onychiopsis psilotoides, yet it is impossible to distinguish these from a large number here referred to Cladophlebis alata. For instance, the pinna shown in Plate V, figure 3, is not to be separated from figure 5 of Fontaine's plate above cited.

On the whole it seems best, pending the finding of additional material, to leave this form under the name given it by Fontaine, with the frank confession that such disposition is recognized as neither adequate nor final.

1 Berry, E. W., Maryland Geol. Survey, Lower Cretaceous, p. 243, 1912.

2 Seward, A. C., Fossil plants of the Wealden, pt. 1, Pl. II, fig. 1, 1894

${ }^{3}$ Fontaine, W. M. U. S. Geol. Survey Mon. 48, p. 155, PI. XXXIX, figs. 3-6, 1905. 


\section{Equisetum COLLIERI n. sp.}

Plate V, figure 5.

Stem very little flattened or distorted, about 6 or 7 millimeters in diameter and about 5.5 centimeters long between the nodes, slightly swollen in the nodal region, and with about eight relatively very strong longitudinal ribs and corresponding channels; sheath very short, appressed; teeth apparently of the same number as the ridges, about 12 millimeters in length, slender and sharply acuminate at apex, each lying closely appressed in a groove; tubercles, or enlarged subterranean portions, present at the lower node.

This species is based on the only example noted in the Collier collections and has been named for the collector. As may be seen, it has been little flattened or otherwise distorted and may be viewed nearly in its entirety. It is chiefly remarkable for the very prominent ribs and corresponding channels, and the short sheath with the long, slender acuminate teeth closely appressed in the depressions.

I have very little doubt that this is the same as the form from Cape Boheman, Spitzbergen, described by Heer ${ }^{1}$ under the name Equisetum rugulosum, though the present form is better preserved and admits of a fuller description of the essential characters. The size and the prominent ribs are evidently similar in both, though the Spitzbergen specimen is not swollen in the nodal region, and of course the character of the teeth can not be made out. Rather than make a doubtful identification, however, I have placed the Alaska specimen under a different name.

This species is also similar to the specimen of Equisetum burejense from Amurland shown in one of the figures given by Heer. ${ }^{2}$ This figure shows a portion of a stem with parts of two nodes and an attached "tuber," as well as several scars, whence apparently other "tubers" have been broken. The figure of $E$. collieri shows the presence of a "tuber" of similar size and appearance, at least so far as can be made out, at the lower node. The size of the stem is similar in the two forms, though $E$. burejense is not swollen in the nodal region nor are the longitudinal ridges so prominent.

Seward, ${ }^{3}$ in commenting on Equisetum burejense, says: "These incomplete specimens may be tubers of Equisetites, but they are hardly worthy of a specific name." This attitude of mind in dealing with obscure or biologically uncertain forms is not the right one, in my opinion, for if a plant is sufficiently well characterized to be used as a stratigraphic mark its usefulness is increased by giving it a definite name that can be employed for reference, whether it is biologically allocated or not.

Nathorst," who reviewed Heer's Cape Boheman material, reduced not only his Equisetum rugulosum but also E. bunburyanum Heer and Phytotheca lateralis? Heer to Equisetites sp., remarking that they are too poorly preserved and doubtful to be maintained. The fine transverse lines on Equisetum rugulosum spoken of by Heer are, according to Nathorst, only checks in the carbonaceous covering. Be this as it may, there does not appear to be any doubt as to the correctness of referring the present Alaska form to Equisetum.

\section{Otozamites giganteus Thomas.}

Plate VI, figure 2.

Otozamites giganteus Thomas, Jurassic flora of Kamenka: Com. géol. Mém., new ser., pt. 71, p. 84, Pl. VI, figs. 1, 2, 1911.

The single example figured is the only specimen of this species that has been found. It consists of a portion of the rachis about 4 centimeters in length and the basal portions of three leaflets, only one of which, however, is anywhere near perfect. This most perfect leaflet is 13 millimeters wide and is preserved for a length of about 4.5 centimeters and was presumably

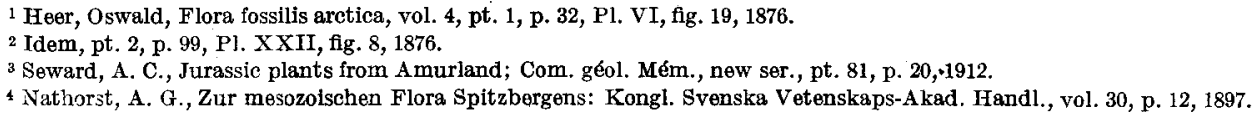


some 7 or 8 centimeters in length when living. The base is plainly heart-shaped, with the upper side slightly the longer and apparently a little overlapping the rachis; the point of attachment is approximately in the center of the leaflet. The margins of the leaflet are completely preserved only near the base, but so far as can be made out little narrowing is apparent. The nervation all arises at the point of attachment and thence radiates out with occasional forking to accommodate the enlarged area reached.

The type locality for Otozamites giganteus is Kamenka, in the district of Izium, in beds of Bathonian age (= upper part of Middle Jurassic or Brown Jura), and until the present record the species had not been found elsewhere.

\section{Zamites megaphyllus (Phillips) Seward.}

Plate VII, figure 1.

Zamites megaphyllus (Phillips) Seward, Jurassic flora, pt. 2, Pl. X, figs. 4, 5; Pl. XII, figs. 1, 3-5, 1904.

Palæozamia megaphylla Phillips, Geology of Oxford, p. 169, Diag. XXX, fig. 6, 1871.

Irites alaskana Lesquereux, U. S. Nat. Mus. Proc., vol. 10, p. 36, 1887.

Baiera palmata Heer, Lesquereux, idem, vol. 11, p. 31, Pl. XVI, figs. 4, 5, 1888.

Nageiopsis longifolia Fontaine, in Ward, U. S. Geol. Survey Mon. 48, p. 171, Pl. XLV, figs. 1-5, 1905.

Podozamites grandifolius Fontaine?, idem, p. 167, Pl. XLIV, fig. 1.

Leaflets coriaceous in texture, long, narrow, strap-shaped, slightly falcate, abruptly rounded at base, narrowed from or below the middle to a long, slenderly acuminate apex; margin perfectly entire; attachment unknown but probably sessile by the narrowed base; nerves distinct, parallel, not forking unless at base (which has not been clearly seen), 20 or 25 in number, each separated by about 10 thin, very delicate intermediate veins.

This species is represented by nearly twenty examples, none of which is absolutely complete, as all lack the extreme base showing the point of attachment. The character of the extreme tip, however, is well shown in several specimens. The maximum length observed is about 18 centimeters and the width 2.5 to nearly 3 centimeters. At least two of the specimens show that the base is becoming rounded to the point of attachment, but unfortunately none is quite clear at this place. The character of the nerves, both the larger and the fine intermediate ones, is plainly discernible in most of the specimens; they are fully described above.

It was at first my intention to describe this as a new species of Zamites, but on further consideration I found it impossible to distinguish the form from Zamites megaphyllus (Phillips), as described and figured by Seward ${ }^{1}$ from the Great Oolite (Bathonian) of Stonesfield, England. Although Seward states that the English material consists almost entirely of detached leaflets, he was enabled to give the following diagnosis:

Frond pinnate, pinnæ attached to the rachis at a wide angle, reaching a length of more than 30 centimeters and a breadth of over 3 centimeters; linear in form, attached by a slightly contracted concave basal surface, which is somewhat thickened; the lamina tapers gradually to an elongated acuminate apex, frequently falcate near the tip. Veins numerous and parallel, converging slightly toward the base and apex of the pinnæ.

This diagnosis, it will be observed, agrees absolutely with that drawn from the Alaska specimens. In the largest example figured by Seward, ${ }^{2}$ which was 4 centimeters wide, the "lamina is traversed by numerous parallel veins between which, as shown in the drawing, occur finer longitudinal lines." In this particular, therefore, the specimens from Cape Lisburne agree with the English species and apparently there can be no doubt as to their being correctly referred to it.

There has been much uncertainty as to the generic reference for these fine leaflets. The first examples of this form were obtained at the Corwin mine, in the Cape Lisburne region, about 1885, by Henry D. Woolfe. These were studied by Lesquereux, who named them Irites alaskana on account of their presumed resemblance to leaves of the living Iris. He described them as follows: "Leaves thickish, linear-lanceolate, tubulose at apex, narrowed to the base, falcate, equinerved; median nerve obsolete; the lateral broad, equal." He also adds that the "nerves are about 1 millimeter in width [apart], not very prominent, equal, not 
separated by intermediate veinlets, very distinct." I have examined these specimens, which are preserved in the United States National Museum, and find them indistinguishable from the Collier specimens, except in size. The specimens of "Irites alaskana," with additional examples collected at the same locality by H. D. Dumars in 1890, were studied by Fontaine and referred to Nageiopsis longifolia Fontaine, a very abundant form in the Patuxent formation of Virginia and Maryland. It has long been my opinion, and in this I am supported by E. W. Berry, ${ }^{1}$ that these specimens from Cape Lisburne have absolutely nothing to do with Nageiopsis nor of course with Irites. They have been compared carefully with the type and typical material of Nageiopsis longifolia Fontaine, and they are not the same. It is believed that they are not even congeneric. ${ }^{2}$

I am also referring to Zamites megaphyllus the specimens that Lesquereux ${ }^{3}$ referred to Baiera palmata Heer and that Fontaine later referred with question to Podozamites grandifolius Fontaine. Both these authors fell into the error of regarding these leaves bottom side upthat is, as may be seen on referring to Lesquereux's figure 4, the part figured as the base is in reality the apex. Fontaine, ${ }^{4}$ in speaking of these specimens, expressed doubt as to their affinity but finally referred them to his Podozamites grandifolius, which is now placed under Ctenopsis latifolia (Fontaine) Berry, ${ }^{5}$ a rather rare species of the Patuxent formation of Virginia. Although these leaflets are if anything even larger than the Collier specimens here figured, they do not differ otherwise, at least so far as can be made out from their somewhat fragmentary condition.

\section{Phonicopsis speciosa Heer.}

Plate VIII, figures 2-4.

Phonicopsis speciosa Heer, Flora fossilis arctica, yol. 4, pt. 2, p. 112, Pl. XIX, figs. 1, 2; P1. XXX, figs. 1-6, 1876.

There are several examples in the Collier collections that clearly belong to Phonicopsis speciosa as described and figured by Heer from Amurland. Three of these have been figured, the one shown in Plate VIII, figure 2, being the most perfect. Another (Pl. VIII, fig. 3) is a detached leaflet or segment 11 centimeters in length and nearly 1 centimeter in width, which is indistinguishable from the specimen shown in Heer's Plate XXX, figure 3. Apparently this very characteristic species has not previously been recorded from North America.

\section{Phenicopsis angustifolia Heer.}

Phnenicopsis angustifolia Heer, Flora fossilis arctica, vol. 4, pt. 2, pp. 51, 113, Pl. I, fig. Id; PI. II, fig. 3b; 1876.

The Collier collection contains several fragments that appear certainly to belong to Phonicopsis angustifolia. Whether this species is really distinct or is referable to $P$. speciosa, as Seward ${ }^{6}$ suggests, must be left to the future to determine. The present specimens are to be identified with $P$. angustifolia but throw no light on the question of their identity with $P$. speciosa.

\section{Podozamites lanceolatus (Lindley and Hutton) Fr. Braun.}

Podozamites lanceolatus (Lindley and Hutton) Fr. Braun (non Emmons), Verzeichniss der in der Kreis-NaturalienSammlung zu Bayreuth befindlichen Petrefacten, p. 100, 1840; Heer, Flora fossilis arctica, vol. 4, pt. 1, p. 35, Pl. VII, figs. 1-7, 1876; idem, pt. 2, p. 106, P1. XXIII, figs.1c, 4a-c; Pl. XXVI, figs. 2-10; P1. XXVII, figs. 1-8, 1876.

The typical form of this variable type is represented by only a few fragments of rather large leaves that are too poor to figure.

\footnotetext{
1 Maryland Geol. Survey, Lower Cretaceous, p. 385, 1911.

2 Since the above was written Hamshaw Thomas has published a short paper (Some new and rare Jurassic plants from Yorkshire: Cambridge Philos. Soc. Proc., vol. 17, pp. 256-262, Pls. VI, VII, 1913) in which he has described a new type of ginkgodian leaf under the name Eretmophyllum. In discussing the relationship of this new form Thomas suggests the possibility that these specimens, referred by Fontaine to Nageiopsis longifolia, may really be referable to his Eretmophyllum. Continuing, he says: "Fontaine's figure 5 might possibly be an Eretmophyllum leaf figured upside down, and the shape of the other fragments, thin distant veins almost parallel but sometimes forking, presents some points of similarity." A comparison of the specimens studied by Fontaine, as well as the Collier specimens here figured, shows that this suggestion is not without weight. This may account for the fact that the leaves or leaflets are always isolated, and further they may have been improperly oriented. However, until further proof is forthcoming, it seems as well to leave them under Zamites.

${ }^{3}$ Lesquereux, Leo, U. S. Nat. Mus. Proc., vol. 11, Pl. XVI, figs. 4, 5, p. 31, 1888.

4 Fontaine, W. M., U. S. Geol. Survey Mon. 48, p. 167, 1905.

- Berry, E. W., Maryland Geol. Survey, Lower Cretaceous, p. 349, 1911.

- Seward, A. C., Jurassic plants from Amurland; Com. géol. Mém., new ser., pt. 81, p. 21, 1912.
} 
Podozamites lanceolatus eichwaldi (Schimper) Heer.

Plate V, figure 6; Plate VI, figure 5, part.

Podozamites lanceolatus eichwaldi (Schimper) Heer, Flora fossilis arctica, vol. 4, pt. 2, p. 109, P1. XXIII, fig. 4; Pl. XXVI, figs. 2, 3, 9; Pl. XXVII, figs. 1, 5c, 1876; Nathorst, Zur mesozoischen Flora Spitzbergens: Kongl. Svenska Vetenskaps-Akad. Handl., vol. 30, p. 13, Pl. I, fig. 5, 1897.

Podozamites eichwaldi Schimper, Traité de paléontologie végétale, vol. 2, p. 160, 1870; Heer, Flora fossilis arctica, vol. 4 , pt. 1, p. 36, Pl. VI, fig. 22c; Pl. VII, fig. 7c; Pl. VIII. figs. 1-4, 1876.

Podozamites lanceolatus latifolius (Schenk) Heer, Knowlton, in Collier, U. S. Geol. Survey Bull. 278, p. $29,1906$.

This form is very abundant and excellently well preserved in the Collier collections, and Heer also speaks of it as being an abundant form in the sandstones at Cape Boheman, Spitzbergen. At first Heer described it with full specific rank, but later he inclined to regard it as merely a variety of the omnipresent $P$. lanceolatus, and this is the view taken by Nathorst, who restudied Heer's specimens together with much additional material. Nathorst states that three forms of $P$. lanceolatus are present at Cape Boheman-P. lanceolatus genuinus, $P$. l. eichwaldi, and $P$. $l$. ovalis. It is quite possible that a large series might show that these forms so intergrade as to make it unsatisfactory to attempt to draw any sharp lines between them, but in the present collection they appear very distinct. For stratigraphic purposes the variety eichwaldi is certainly well marked, a fact which is of interest in the present connection as tending to connect the Cape Lisburne region with other undoubted Jurassic localities.

\section{Elatides curvifola (Dunker) Nathorst.}

Plate VIII, figure 1.

Elatides curvifolia (Dunker) Nathorst, Zur mesozoischen Flora Spitzbergens: Kongl. Svenska Vetenskaps-Akad. HandI vol. 30, p. 35, Pl. I, figs. 25-27; Pl. II, figs. 3-6; Pl. IV, figs. 1-18; Pl. VI, figs. 6-8, 1897.

Lycopodites curvifolius Dunker, Monographie der norddeutschen Wealdenbildung, p. 20, P1. VII, fig. 9, 1846.

The single fragmentary example figured is all that was noted of this species.

Pagiophyllum kurrit. (Pomel) Schimper.

Plate VI, figure 1.

Pagiophyllum kurrii (Pomel) Schimper, Traité de paléontologie végétale, vol. 2, p. 250, 1872; Möller, Bornholms fossila Flora, Gymnospermer: Kongl. Svenska Vetenskaps-Akad. Handl., vol. 36, p. 31, Pl. V, figs. 10-12, 1903. Araucaria peregrina p. p., Kurr, Beiträge zur fossilen Flora der Juraformation Württembergs, p. 9, Pl. I, fig. 1, 1846. Moreauia kuhrii Pomel, Matériaux pour servir à la flore fossile Jurassique de la France, p. 21, 1849.

This species, described originally from the Jurassic of Wurttemberg, was found by Möller at Bornholm in beds regarded as either Rhætic or Liassic. Whether Möller has been correct in determining the Bornholm plants as identical with Pagiophyllum kurrii need not be discussed at this time, but it is certain that the specimens so figured and named by him are not to be distinguished from the Cape Lisburne example here figured. For instance, Möller's Plate V, figure 12, shows a short branchlet with broad, rather obtuse leaves that is certainly the same as the specimen from Cape Lisburne.

On the same piece of matrix and lying very close to the branchlet from the Collier collection is the apical portion of another branchlet which may or may not represent a very immature cone. It is not well preserved and hence can not be made out with certainty. Just below the "cone" are two or three leaves of the same size and appearance as those on the adjacent branchlet; below these the leaves become crowded and apparently narrower and shorter. It is, on the whole, probable that this is merely a growing tip in which the leaves are not fully developed. 


\section{Pagiophyllum steenstrupi Bartholin?}

Pagiophyllum steenstrupi Bartholin, Nogle i den bornholmske Juraformation forekommende Planteforsteninger, p. 101, Pl. V, figs. 6-8; Pl. VI, figs. 1, 2, 4, 1894; Möller, Bornholms fossila Flora, Gymnospermer: Kongl. Svenska Vetenskaps-Akad. Handl., vol. 36, p. 33, Pl. VI, figs. 1-3, 1903.

The Cape Lisburne material contains two minute fragments that appear to be the same as the tips of branchlets such as are shown in Plate VI, figure 3, of Möller's paper, cited above, but they are so small and uncertain as to make their identification more or less questionable:

These specimens also suggest Stachyotaxus septentrionalis (Ag.) Nathorst, as figured by Möller, ${ }^{1}$ but there is not enough preserved to identify them certainly with that species.

Pityophyllum noRdenskiöldi (Heer) Seward.

Pityophyllum nordenskiöldi (Heer) Seward, Jurassic plants from Amurland: Com. géol. Mém., new ser., pt. 81, p. 30, Pl. II, fig. 17; Pl. III, fig. 22, 1912.

Pinus nordenskiöldi Heer, Flora fossilis arctica, vol. 4, pt. 1, p. 45, Pl. IX, figs. 1-6, 1876; idem, pt. 2, pp. 76, 117, Pl. IV, fig. 8c; Pl. XX, fig. 4, a, b; Pl. XXVII, fig. 9a; Pl. XXVIII, fig. 4, 1876.

This form is represented in the present material by several small fragments which are about 3 millimeters in width and 2 or 3 centimeters in length, evidently from the middle portion of the leaves. They have a single very strong median rib and show distinctly the peculiar transverse wrinkling so well known in leaves of this type. One fragment appears to show the presence of the longitudinal groove in the middle of the lamina that is regarded by Nathorst as so characteristic of this species, though the others in close proximity to it do not. It is probable, as Nathorst has suggested, that the transverse wrinkling is in the main a phenomenon of desiccation, though it was doubtless more or less connected with some structural peculiarity.

As Seward ${ }^{2}$ has very well said, it is extremely difficult, if not impossible, satisfactorily to distinguish between many of the Rhrtic and Jurassic leaves that have been described from time to time under the name Pityophyllum. Thus I can see no marked distinction between what is here called $P$. nordenskiöldi and. $P$. staratschini (Heer) Nathorst, ${ }^{3}$ from Advent Bay, Spitzbergen. It also agrees closely with Taxites cf. gramineus (Heer) as figured by Nathorst ${ }^{4}$ from Franz Josef Land. Seward ${ }^{5}$ has suggested that the leaves from the, Jurassic of Oregon referred by Fontaine ${ }^{6}$ to Nilsonia parvula (Tæniopteris parvula Heer) are to be regarded as belonging to Pityophyllum, but this can hardly be so, for they are much larger than any usually referred to Pityophyllum, and moreover they have a lateral nervation exactly as figured by Heer under Tæniopteris parvula.

Fieldenia noRdenskiöldi Nathorst.

Plate VII, figure 2.

Fieldenia nordenskiöldi Nathorst, Zur mesozoischen Flora Spitzbergens: Kongl. Svenska Vetenskaps-Akad. Handl., vol. 30 , p. 56, Pl. III, figs. 16-27, 1897.

In the material from Cape Lisburne I find several more or less well preserved leaves that I am unable to distinguish from Nathorst's species, which comes from the Upper Jurassic of Advent Bay, Spitzbergen. The example figured is nearly perfect except that the nervation is rather indistinct, though careful scrutiny discloses the presence of about eight thin, parallel nerves. The point of the leaf is obtuse and rounded, the basal portion is narrowed to the point. of attachment, and on the whole this leaf is absolutely indistinguishable from that shown in figure 17 of Nathorst's Plate III.

As Nathorst has pointed out, it is difficult, if not impossible, to distinguish between the present species and what Heer ${ }^{7}$ has called Podozamites ensiformis and P. cuspiformis from the Irkutsk, eastern Siberia.

\footnotetext{
1 Op. cit., Pl. V, fig. 7 .

2 Seward, A. C., Jurassic plants from Amurland: Com. géol. Mém., new ser., pt. 81, p. 30, 1912.

3 Nathorst, A. G., Zur mesozoischen Flora Spitzbergens: Kongl. Svenska Vetenskaps-Akad. Handl., vol. 30, p. 68, Pl. V, figs. 32-36, 1897.

4 Nathorst, A. G., Fossil plants from Franz Josef Land: Norwegian North Polar Exped., vol. 1, No. 3, Pl. II, figs. 20-23, 1900.

- Sew

- Fontaine, W. M., U. S. Geol. Survey Mon. 48, P1. XVII, figs. 1-7, 1905

7 Heer, Oswald, Flora fossilis arctica, vol. 4, pt. 2, Pl. IV, flgs. 8-10, 11, 12, 1876
} 
Ginkgo digitata (Brongniart) Heer.

Plate VI, figure 5, part; Plate VII, figures 3-5.

Ginkgo digitata (Brongniart) Heer, Flora fossilis arctica, vol. 4, pt. 1, p. 40, P1. X, figs. 1, 5a, b, 6, 1876.

Ginkgo huttoni (Sternberg) Heer, Fontaine, in Ward, U. S. Geol. Survey Mon. 48, p. 170, 1905.

Ginkgo huttoni magnifolia? Fontaine, idem, p. 170, P1. XLIV, figs. 7, 8.

Ginkgo multinervis. Heer, Lesquereux, U. S. Nat. Mus. Proc., vol. 11, p. 31, Pl. XVI, fig. 6, 1888.

Leaves of Ginkgo are abundant in the Cape Lisburne collections, and it was undoubtedly a conspicuous element in this flora, as indeed it must have been in all the northern Jurassie and early Cretaceous floras. In the Oregon collections, for instance, the genus is represented literally by hundreds of specimens, and it was equally abundant throughout eastern Siberia.

This genus has been very much overburdened, for in dealing with such an abundance of specimens and multiplicity of forms one must needs make either many "species" to accommodate this diversity, or only one or two, and in view of the known variation exhibited by the single living species, the latter plan seems preferable. As a consequence, all the Alaska specimens are here considered as referable to the extremely variable Ginkgo digitata.

The first Ginkgo leaf known from Cape Lisburne-namely, that found in Woolfe's collection-was identified by Lesquereux as $G$. multinervis Heer, a species described from the Cenomanian beds of Atane, Greenland. The same specimen was later referred by Fontaine to $G$. huttoni (Sternberg) Heer, but while the segments are cut nearly to the base, it does not differ essentially from many referred to $G$. digitata.

The two rather fragmentary leaves from the Dumars collection Fontaine referred with a question to his $G$. huttoni magnifolia, ${ }^{1}$ named from the Jurassic of Douglas County, Oreg. The validity of this variety will not be discussed at this time, and it is sufficient to say that the two specimens from Cape Lisburne are here referred to $G$. digitata.

1 Fontaine, W. M., U. S. Geol. Survey Mon. 48, p. 124, PI. XXXI, figs. 4-8; PI. XXXII, figs. 1, 2, 1905 
.

t.

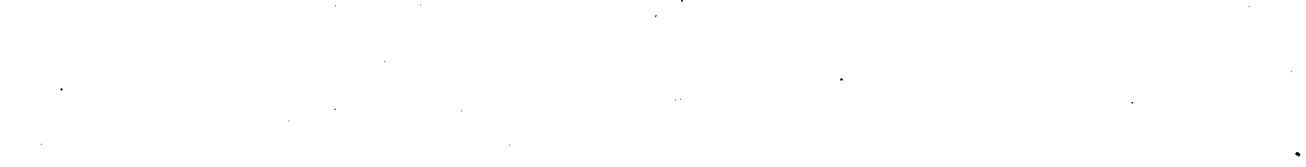

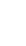

. 
PLATE V.

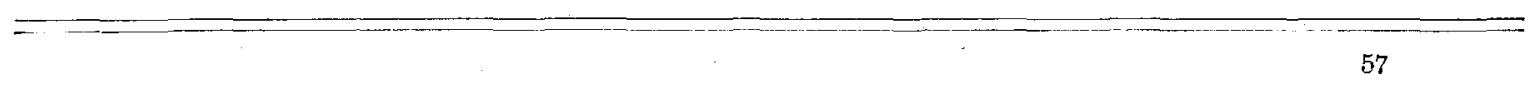




\section{PIATE V.}

Frgure 1. Coniopteris burejensis (Zalessky) Seward.

2. Coniopteris hymenophylloides (Brongniart) Seward.

3, 4. ? Cladophlebis alata Fontaine.

5. Equisetum collieri $\mathrm{n} . \mathrm{sp}$.

6. Podozamites lanceolatus eichwaldi (Heer) Seward. 


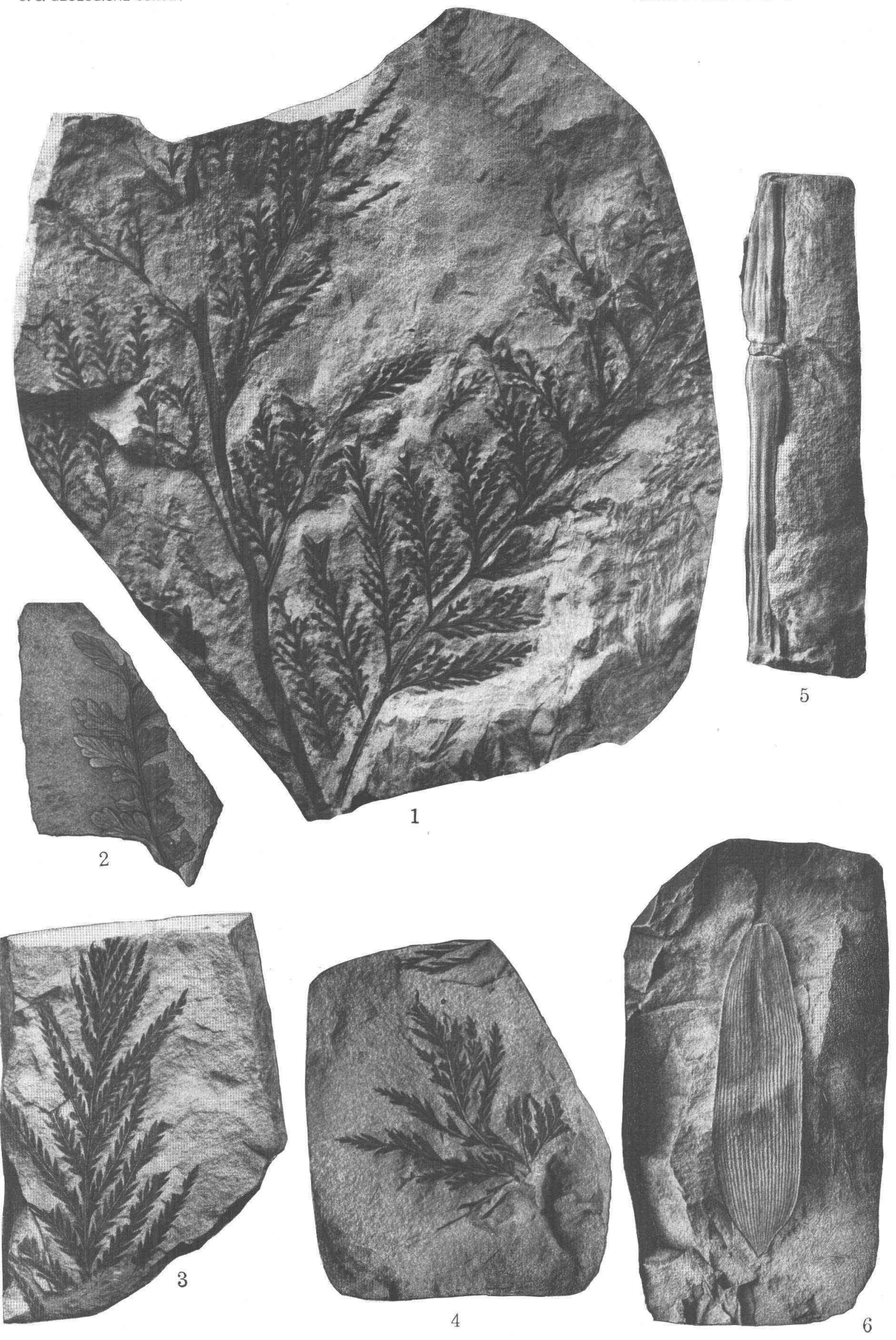

JURASSIC FLORA OF CAPE LISBURNE, ALASKA. 

PLA'TE VI. 


\section{PLATE VI.}

Figure 1. Pagiophyllum kurrii (Pomel) Schimper.

2. Otozamites giganteus Thomas.

3. Cladophlebis huttoni (Dunker) Fontaine.

4. ? Cladophlebis alata Fontaine.

5. Ginkgo digitata Heer and Podozamites lanceolatus eichwaldi (Heer) Seward. 


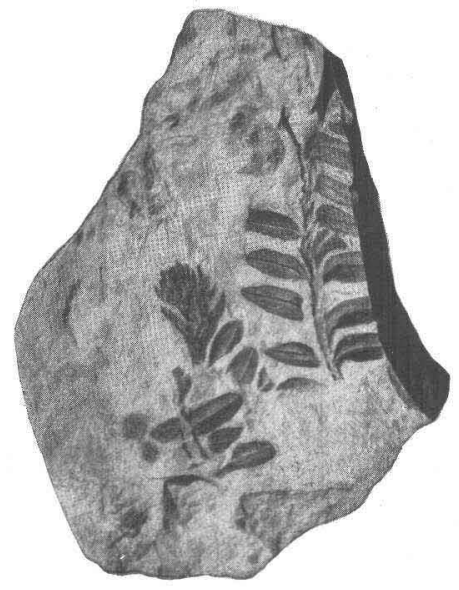

1

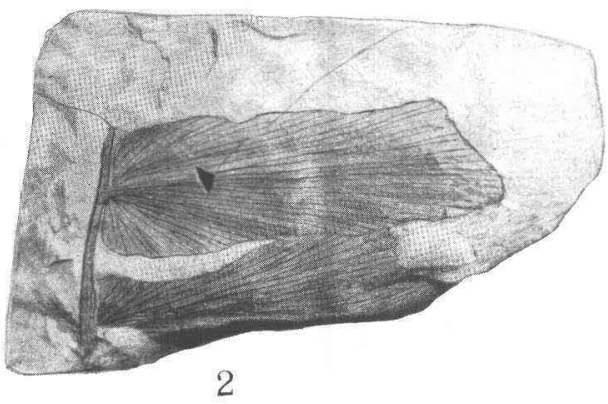

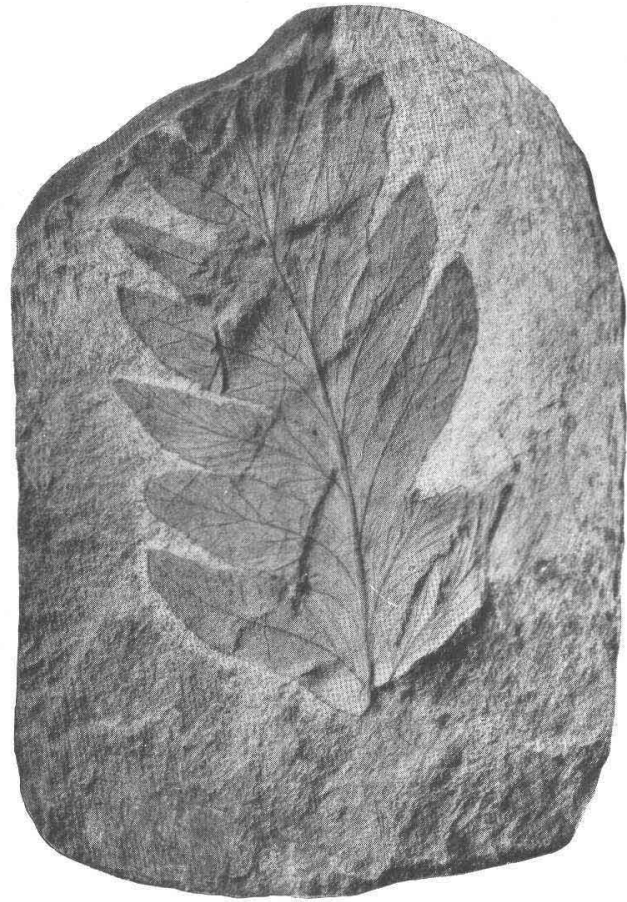

3
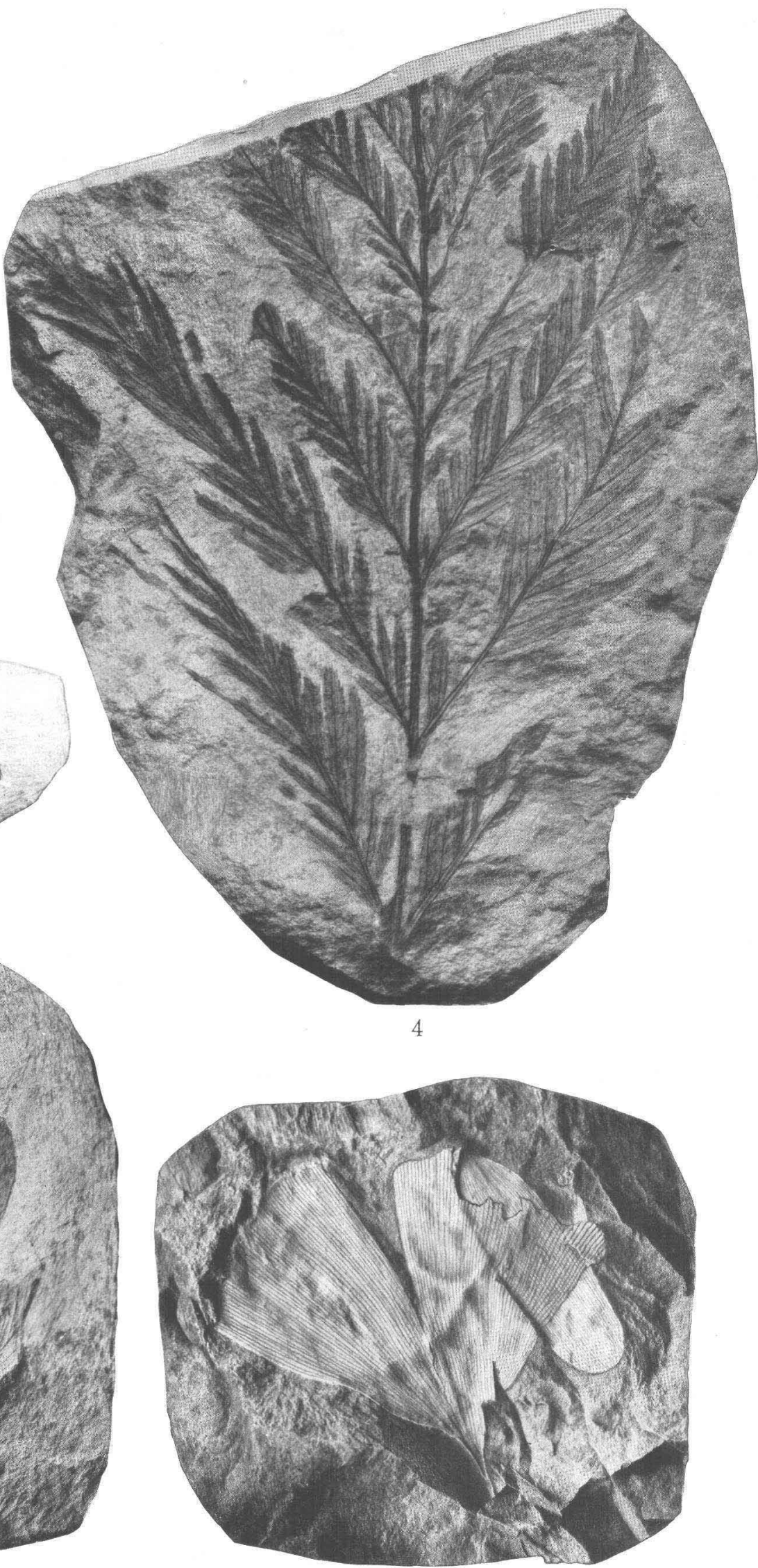

5

JURASSIC FLORA OF CAPE LISBURNE, ALASKA. 



\section{PLATE VII.}


PLATE VII.

Figure 1. Zamites megaphyllus (Phillips) Seward.

2. Fieldenia nordenskiöldi Nathorst.

3-5. Ginkgo digitata Heer.

62 
U. S. GEOLOGICAL SURVEY

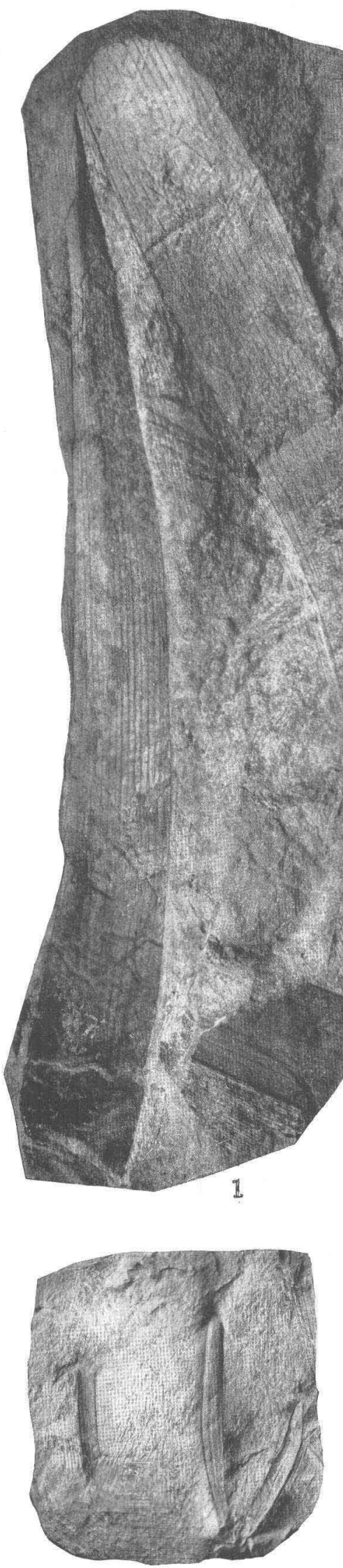

2
PROFESSIONAL PAPER 85 PLATE VII
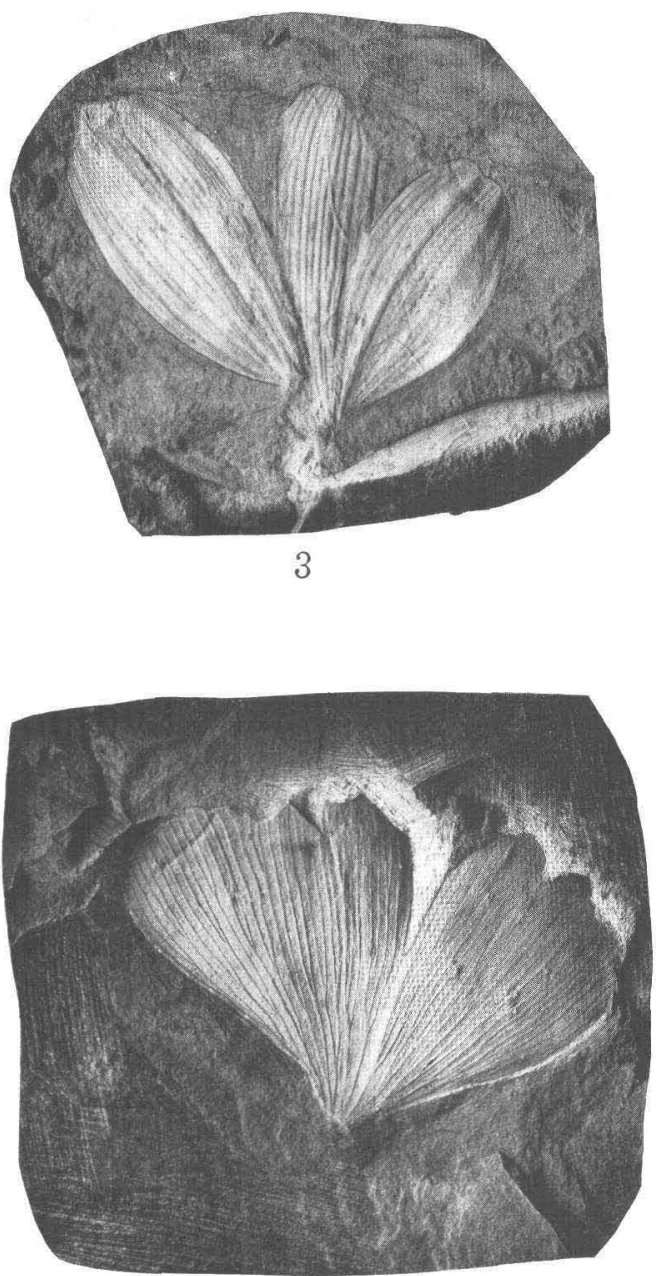

4

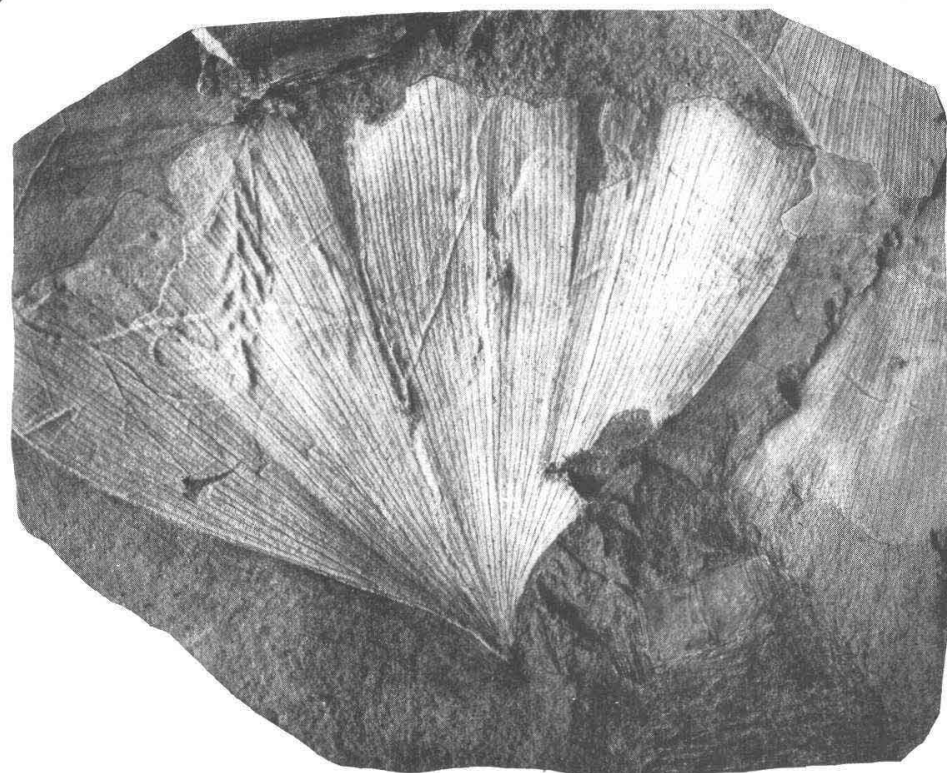

5

JURASSIC FLORA OF CAPE LISBURNE, ALASKA. 
PLATE VIII. 
PLATE VIII.

Figure 1. Elatides curvifolia (Dunker) Nathorst. 2-4. Phenicopsis speciosa Heer.

64

O 
PROFESSIONAL PAPER 85 PLATE VIII
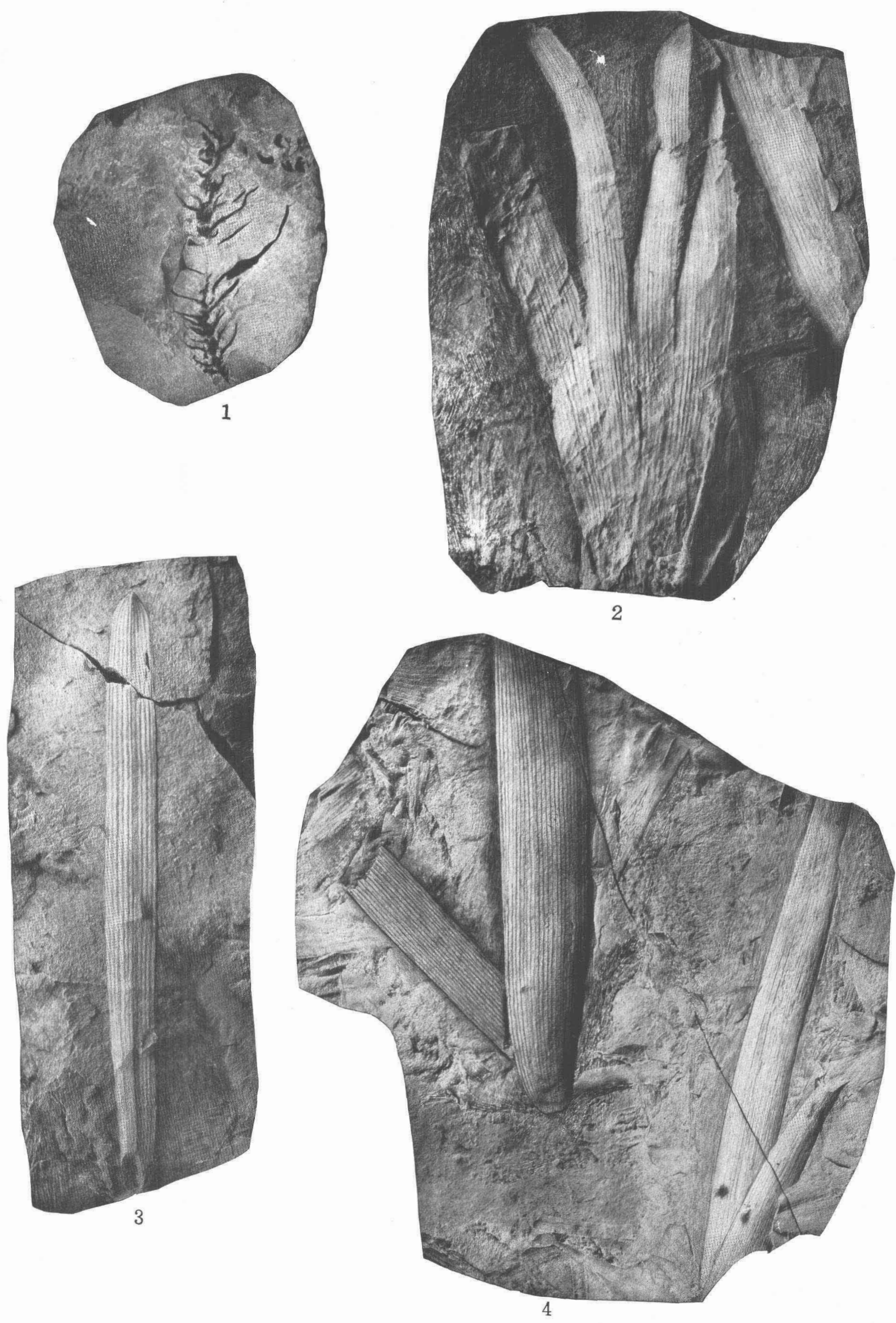

JURASSIC FLORA OF CAPE LISBURNE, ALASKA. 
a

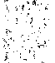

4 